\title{
The Constitutional Principle of Government by People: Stability and Dynamism
}

\section{Sergey Sergeyevich Zenin}

\author{
Candidate of Legal Sciences, Associate Professor, Constitutional and Municipal Law Department \\ Kutafin Moscow State Law University, Russia, Senior Researcher, Russian Penitentiary Service Research Institute \\ zeninsergei@mail.ru
}

\author{
Doi:10.5901/mjss.2015.v6n5p169
}

\section{Abstract}

The article deals with theoretical aspects of the constitutional principle of government by people and its multidimensional nature. The study shows that the principle of the government by people is not a static phenomenon, and it finds its development at the international and national levels. One of the trends of modernization of the content of this principle is its universal international legal acts. At the same time, in the national legal systems, the content of this principle also finds its consistent development to the Constitution, legislation, and practice of Constitutional justice. The article reveals the importance of the principle of government by people in the mechanism of interaction between the state and the people.

Keywords: constitution; principle; government by people; democracy; development

"It is the society, in which people enjoy their supreme power, which is the true repository of freedom", Marcus Tullius Cicero

\section{Introduction}

In modern societies people can be passive, but they always play an indispensable role in political relations. This is an organic element of political alchemy, which is essential to the existence of a modern democratic state. The recognition of the will of people as the basis of construction and operation of a modern state was a new starting point for the development of universally recognized values. The legal consequence of this recognition was the creation of a new constitutional principle - the principle of government by people, the content of which was formed by combining the ideas of free will of people and people's representation in the single constitutional legal doctrine. It's the French Declaration of Human Rights that first proclaimed that only the nation is the source of sovereignty, that no person, no institution can exercise power, that isn't derived directly from the people.

Above all, government by people is a historical category, which is transformed under the influence of a number of factors. This phenomenon finds its legal interpretation in national legal systems under the influence of cultural, economic and political characteristics of a particular state. In this regard, the identification of patterns of constitutional and legal development of government by people will constitute the idea of the prospects and the main directions of social progress in this area.

Thus, the purpose of this article is to represent scientific understanding and formulate theoretical foundations of the legal development of the constitutional principle of government by people.

\section{Methodology}

Methodological basis of the study is the dialectical method of knowledge of social and legal phenomena. Government by people as a phenomenon of modern society is in constant development, which is reflected in the existing national legal systems and international law. Embodied in the legal field in the form of a constitutional principle, government by people has become one of the foundations of a modern democratic state and civil society. Acting as a part of a whole, government by people is in deep relationship with other elements inherent to the democratic doctrine. Their mutual influence is the driving force that energizes the development of democracy and forms new connections affecting all spheres of public life. The dialectics of government by people is manifested in its institutional processes and has been identified as a system with some internal elements that interact and develop the content of this system.

Thus, the hypothesis of this study is that government by people as a constitutional principle is not static, once and for all. It is in constant development, the result of which is to maintain form while changing the content. Using a method of 
analysis and synthesis, we can consider the internal contents of this constitutional principle. We also use the deductive method to identify common patterns of development of this principle on the international legal level. On the basis of comparative legal method we can identify the main directions of development of the principle of government by people in national legal systems. Trough modeling and simulation we can generate understanding of the theoretical foundations of government by people. The combination of general logical analysis, theoretical and empirical methods allowed us to form a scientific understanding of the theoretical basis of the development of the constitutional principle of government by people.

\section{The Stability of Government by People}

For quite a long period of its existence in the legal field, the principle of government by people has been quite popular for public discussion. Today, it is fixed in the constitutions of most countries, and it proves to be well recognized, but the views on its content may be controversial. For example, the Constitution of the Italian Republic stipulates as its fundamental principle that sovereignty belongs to the people, who exercise it in the forms and within the limits established by the Constitution. In Article 20 of the Basic Law of the Federal Republic of Germany it's fixed that all state authority emanates from the people, who exercise it through elections and other votes and through specific legislative, executive, and judicial power. The Spanish Constitution states that the bearer of national sovereignty is the Spanish people being the source of the state power. The Constitution of the Russian Federation stipulates that the bearer of sovereignty and the only source of power in the Russian Federation is its multinational people, who exercise their power directly and through bodies of the state power and local self-government.

The content of the above legal norms suggests that national legal systems at the constitutional level form a unified approach to the definition and the content of the constitutional principle of government by people. In this regard, a binding element of the constitutional principle of government by people may include sovereignty, will, and power of people. In the variety of options to the descriptions of these phenomena, based upon the national constitutions, the core of the constitutional and legal principles of government by people is being formed and exercised. However, there are some circumstances that can have direct impact, changing its components and to some extent transforming its meaning.

Thus, the principle of government by people must be seen as a complex phenomenon, consisting of at least three distinct levels. The first level is national, the second is public, and the third one is democratic. The national level is represented by a set of values as a single political, historical and cultural community of multinational people living on the territory of the state. These ideas form a core of any social system, and their combination is one of the foundations of the constitutional principle. National characteristics have a significant impact on the social stratum, which includes economic, political, spiritual and social foundations of government by people. The third level - democratic - combines recognized liberal values. The history shows this is the most volatile component of the principle of government by people (Mueller Y.V., 2014). Continuous development of democratic thought creates endless search for new approaches to the implementation of the existing public institutions that help develop the content of this constitutional principle.

Revealing a constitutional and legal position of the content of the principle of government by people as a complex but stable phenomenon, we recognize the following components:

1. The failure to establish the state reason to exclude individuals or groups from the people;

2. Recognition of people as the bearer of supreme power;

3. Establishment of the will of people as a guideline for the development of state and law;

4. Free exercise of people's power in a legal form;

5. The formation of governmental bodies based on free will of the people;

6. Possibilities of people's control over the functioning of public authorities;

7. People's participation in the implementation of other forms of government;

8. Recognition of the sovereignty of people;

9. Raising people's awareness;

10. Mutual security of the state and its people.

\section{International Standards - Universalization of Government by People}

The development of globalization (John Keane, 2003) in the sphere of economy, politics, cultural and social life influences greatly the development of the constitutional principle being discussed in this article. As a result, in the legal discourse there were established some international standards for the implementation of the government by people principle. This principle is implemented under a significant number of international legal acts that contain special requirements for its 
implementation.

So Article 21 of the Universal Declaration of Human Rights stipulates that the will of the people shall be the basis of the authority of the government. The will of the people is expressed in periodic and genuine elections which shall be by universal and equal right to vote, or suffrage, and by secret vote or by equivalent free voting procedures.

The reduced rate is indicated on the particular importance of the will of people as the foundation necessary for the functioning of the legitimate government, as well as fixed way of objectification of the will and requirements that it must meet. Thus, using the approach of Max Weber, one can conclude that the basis for the functioning of a modern state is organized by a formal legal approach (M.Weber, 1990), which is most fully manifested in the universalization of democracy. The content of this process is more fully reflected in the thesis that today government by people cannot be a purely national phenomenon; it must conform to "outline" the universally recognized values.

In accordance with the provisions of the Vienna Declaration and the Programme of Action of 1993 a modern democracy should be based on the freely expressed will of people to determine their own political, economic, social and cultural systems. People must fully participate in all aspects of their lives. It belongs to the people as the right to freely determine their political status and freely pursue their economic, social and cultural development.

International standardization of government by people, as an integral feature of the modern democratic state is carried out after the universalization of the democratic idea. As stated in the Document of the Copenhagen Meeting of the Conference on Human Dimension, the vitality of democracy depends on the existence as an integral part of national life of democratic values and practices, and a broad range of democratic institutions. States are focused on support for joint practical efforts and exchange of information, ideas and experiences in the framework of direct cooperation between individuals, groups and organizations.

There are instances confirming the on-going process of the development of universalization of democracy and the idea of government by people as its component part. They can be found in the documents of the General Assembly of the United Nations. Thus, in its Resolution of 13 December 20136217 it's stated that democracy does not belong to any country or region, it is a universal value based on the freely expressed will of the people.

In another resolution, the General Assembly of the UN on July 3, 2012 66/285, governments are urged to strengthen national programs for the development of democracy, including the necessity to increase bilateral, regional and international cooperation, taking into account innovative approaches and best practices. Special attention is also paid to the development of cooperation between national parliaments with the media, civil society inter-parliamentary organizations.

Also, the documents of the General Assembly proclaimed the need to establish a united democratic international order that can be provided by promoting and strengthening democratic international institutions in all areas of cooperation; ensure the right to a fair participation of all people in the decision-making process, at both the national and the global levels.

Thus, in the content of a wide variety of international instruments we can observe the target to meet the provisions of the production of universal requirements for implementation of the principle of government by people as an essential element of a democratic political regime. In addition, at the international level are produced not only the general direction of the democratic development of countries, but formulated the general requirements for the functioning of certain institutions of government by people. A striking example of this is the Code of Good Practice in referendums, in which there were for the first time summarized and formulated at the international level the basic principles of the referenda in the states - members of the Council of Europe. Such requirements were also formulated in relation to other institutions of government by people. For example, the Declaration on Criteria for Free and Fair Elections, adopted by the $154^{\text {th }}$ session of the Council of Inter-Parliamentary Union in Paris in 1994, sets international standards for genuine free and fair elections.

Consolidating general directions of the development of government by people in the nation-states, and defining the international requirements for the implementation of certain democratic institutions, we carry out the universalization of government by people. And this is not the universalization aimed at developing such forms that would ensure a comprehensive implementation of this principle in any national context. This is a new universalization, the purpose of which is to create such criteria of the government by people whose properties would be able to change external conditions for its implementation.

Arising antagonism between national characteristics and the universalization of government by people should be resolved by abandoning the idea of forming the only true model of government by people. International recognition of universal democratic values cannot be done without taking into account national peculiarities of states. In this connection, the state in the process of its operation should have the freedom of action for the development of the principle of government by people within its own legal system. The legal scope of this freedom must be found embodied in the 
constitutions of nation-states. In these circumstances, we cannot talk about the absolute universality. It is necessary to retain the possibility of consensus, which should be based on the consent of disagreement - that is critical universalization of government by people.

\section{The Dynamism of Government by People - National Dimension}

The application of such category as "dynamism" to the principle of government by people suggests the possibility of a constant current, existing naturally directed change in the quality and nature of the legal regulation of this basic constitutional principle. The whole set of objective reasons for such changes may be divided into two groups. Firstly, it is the continuous development of social relations due to the evolution of society and the state. The result is the emergence of new fields or forms of social life within, which ensure the implementation of the constitutional principle of government by people. Secondly, there may be incomplete, contradictory constitutional provisions that enshrine the principle. Often in the process of application of law certain gaps and conflicts requiring elimination are revealed.

In legal discourse the principle of government by people is developed by converting the constitutional and legal regulations of public relations in national legal systems. All in all, the development of the principle of government by people is carried out in several directions:

Firstly, through the adoption of new constitutions of nation-states or some change to existing ones. An example can be the adoption of new constitutions in the late twentieth century in some states, which renounced the socialist direction of development. As a result, it significantly modified the content of this constitutional principle.

Secondly, through the adoption of regulatory legal acts developing the provisions of the current constitution. For example, Article 75 of the Constitution of the Italian Republic recognizes the right of national veto (Mezzetti L., 2013), the process of its realization is developed in the relevant law. Often, the content of the norms of the law depends on the quality of implementation of the constitutional principle. In Art. 3 of the Constitution of the Russian Federation it's alleged that the direct supreme power of people, along with free elections, can be exercised in a referendum. In furtherance of the constitutional provisions, the Federal Constitutional Law of June 28, 2004 № 5-FCL "On referendum of the Russian Federation" was adopted, which sets a hard-to-reach mechanism of initiating a referendum by the citizens of Russia. As a result, no referendums at the federal level have been carried out for over 20 years.

Third, the development of the principle of government by people is being well-carried out within the activities of the constitutional justice, exercising constitutional review or oversight. Often, these bodies, bringing the decision on noncompliance of the norms of certain provisions of the Constitution and legal acts, point to the wrong direction of elected legislators in the development of the constitutional principle of government by people. In addition, while interpreting the implementing rules of the current constitution, the courts reveal the content of the principle of government by people and as a consequence improve it.

The development of the principle of government by people can be both positive and negative. In my opinion, we should consider the possible causes of negative influence of this principle. First of all, we must consider some negative transformations in the implementation of the constitutional and legal provisions:

1. Contrary to the objective tendencies of development of public relations. The basis of the constitutional and legal institutions in this case is not the objective need caused by the genesis of social relations, but the political will of individuals, economic or other interests in certain sectors of society, etc.

2. Recognizing the priority of the principle of government by people over other basic constitutional principles. In this case, the development of the principle is wrongly carried out in the absolute priority of government by people in the constitutional order.

3. Excluding the level of economic, social, political, spiritual, legal and social development. In this case, the transformation is uneven without taking into account the specific social conditions.

4. Representing public opposition, with the society denying the reforms. The development is carried out in conditions of increasing contradictions between the state and society, without taking into account the will of the people.

5. Underestimating national, historical and cultural characteristics of the society. The transformation of constitutional and legal rules in this case is not based on the elements of national identity, and as a result undermines national sovereignty.

Thus, all the facts mentioned above serve as the manifestation of the dynamism of the constitutional principle of government by people, when it is transformed into national legal systems. 


\section{Theoretical Basis of the Principle of Government by People}

Evaluating the current trends in the development of government by people we should note the diversity of this principle, while it serves as a certain link, a "cog" in the mechanism of interaction between the state and the people, as it is presented in Figure 1.

Home value in understanding the features of government by people in the present system pictured in Figure 1 is the definition of the subject as the driving force.

In the present mechanism only two subjects can be identified - the people and the state. Let's consider some views around these subjects in detail.

The first option is idealistic. The people are the subject that determines the strength and direction of the movement of the described mechanism. In legal discourse government by people will be considered as the only tool to influence the state. In turn, this leads to the development of the principle in an ever-increasing divergence. The divergence of government by people means the process of formation of new mechanisms for the implementation of government by people. We can talk about both intra institutional and systemic divergence. Intra-institutional divergence is represented in the emergence of new mechanisms for the implementation of government by people in the framework of pre-existing democratic institutions. As an example, there can be an introduction of aggregative referendum along with the applicable constitutional practices. Intra-systemic divergence is connected with the formation of new institutions previously operating in the domestic legal system of the state. An example of this can be the application of new institutions of participatory democracy (Zimmerman J., 1986).

The second option is pragmatic. In this case, the state is the entity that determines the direction of the movement of the elements provided by the system. The state, being a strictly organized system, is capable of acting directly on the people, and indirectly through the use of the institutions of government by people. The state is striving to implement violence capable of changing the legal environment in which the system operates, which also affects the development of the principle of government by people. A pragmatic option on the functioning of this system is the basis of the formation of a controlled democracy (Sheldon S., 2008).

Discussing the options in detail we still represent the broad approach and should admit that the history of human civilization shows that they are not applicable apart from each other, thereby forming a third option - plural, characterized by constant change of the subject being a driving force.

\section{Conclusion}

The complexity and dynamism of social relations concerning the implementation of government by people principle are a prerequisite for the improving the constitutional rule of law, in which this principle is fixed. The development of this principle in national legal systems should not lead to the modernization of its essential content. The provisions concerning the people as the bearer of sovereignty and the only source of power, and constitutional forms of the implementation of this power should remain inviolable.

It is necessary to ensure the development of the constitutional principle of government by people as an integral part of a unified system of the constitutional order. Its modernization should not create conditions for diminishing the value of other democratic principles. In this connection, it is advisable to formulate a number of basic ideas reflecting the main directions of the positive development of government by people in the Russian Federation. Among these may be noted the following issues:

1. Recognition of human rights and freedom as the supreme value.

2. High-quality implementation of the state's obligation to create the conditions for government by people.

3. Ensuring the legality of the regime in the implementation of the constitutional principle of government by people.

4. Compliance with the appropriate balance between direct and representative government by people;

5. Ensuring the development of the principle of government by people based on the principle of sharing the power.

6. Taking into account national and public interests while developing the principle of government by people.

7. Recognition of the principle of legal security of the people.

The solutions to these problems depend on the quality of law-making activities of legislative bodies of state power and effectiveness of the implementation of the constitutional control. The diversification of the principle of government by people is, on the one hand, a condition to ensure its effective implementation in any environment, but, on the other hand, it can become an obstacle to the realization of its true potential. Understanding the laws of the legal development of this 
principle would allow to most fully realize its content in national legal systems and to ensure a high quality process of its universalization.

\section{References}

Basic Law for the Federal Republic of Germany on 23 May 1949. German Bundestag, Berlin 2010.

Declaration of the Rights of Man and Citizen - 1789 / The French Republic: the Constitution and the laws. M., 1989. P. 26-29.

Federal Constitutional Law of June 28, 2004 № 5-FCL (in red. April 24, 2008) "On referendum of the Russian Federation".

John Keane. Global Civil Society. University Press, Cambridge. 2003.

International election standards. Collection of documents: the second edition / Ed. Lysenko V.I. M.: Central Election Commission of Russia, 2009. P. 612 - 613.

Mezzetti. L. Constitutional law. Milan. 2012. P. 203-210.

Mueller Y.V. The debate about democracy: political ideas in Europe of the XX century. Moscow, 2014. 400 p.

Sheldon S. Wolin. Democracy Incorporated: Managed Democracy and the Specter of Inverted Totalitarianism. Princeton University Press. 2008.

Spanish Constitution adopted December 6, 1978.

The Code of Good Practice in referendums. European Commission for Democracy through Law. CDL-AD (2007) 008rev. Research № 371/2006.

The Concluding Document of the Copenhagen Meeting on the Human Dimension of the CSCE. Adopted at the Copenhagen Conference on the Human Dimension of the Security Council of the Council of Europe, June 29, 1990.

The Constitution of the Italian Republic enacted by the Constituent Assembly on 22 December 1947. Senate of the Republic. 2010.

The Constitution of the Russian Federation adopted by popular vote December 12, 1993 // Meeting of the legislation of the Russian Federation. 2014. №31. Art. 4398.

The Universal Declaration of Human Rights (adopted by the UN General Assembly on December 10, 1948) // the Russian newspaper. December 10, 1998.

The Vienna Declaration and Programme of Action. Adopted on 25 June 1993 at the 2nd World Conference on Human Rights // The Diplomatic Bulletin, 1994. Vol. 3 - 4, P.45 - 63.

UN General Assembly resolution "Support for the United Nations system of the efforts of Governments to promote and strengthening of new or restored democracies" 66/285 of July 3, 2012 // UN Doc. A / RES / 66/285.

UN General Assembly resolution "Promotion of a democratic and equitable international order" 67/175 of December 20, 2012 // UN Doc. A / RES / 67/175.

UN General Assembly resolution "Support for the United Nations system of the efforts of Governments to promote and strengthening of new or restored democracies" 62 । 7 of December 13, 2013 // UN Doc. A / RES / 62/7.

Weber M. Politics as a recognition / Selected Works. M.: Progress, 1990, P. 644-706. URL: http://www.venice.coe.int/docs/2007/CDL$A D(2007)$ 008rev-rus.asp.

Zimmerman J. Participatory Democracy: Populism Revived. N. Y. 1986. 